Diabetologia 7, 94-101 (1971)

(C) by Springer-Verlag 1971

\title{
The Effect of 3-Methyl Salicylic (0-Cresotinic) Acid on Plasma Insulin and Glucose Tolerance in Diabetic and Non-Diabetic Subjects
}

\author{
D.E. Hyams, A.N. Howard, I.E. Evans and S.H.H. Davison
}

Department of Geriatric Medicine, Chesterton Hospital, Cambridge; Department of Investigative Medicine, University of Cambridge; West Suffolk Hospital, Bury St. Edmunds; University Department of Biochemistry and Addenbrooke's Hospital, Cambridge, Great Britain

Received: April 6, 1970, accepted: October 24, 1970

Summary. Oral administration of 3-methyl salicylic acid ( $3 \mathrm{MS}$ ) to diabetic and non-diabetic patients in modest doses $(0.9-1.8 \mathrm{~g} /$ day $)$ over several months produced a significant increase in plasma insulin levels, one hour after a glucose load. In $\overline{2}$ diabetic subjects, acute doses had a similar effect. - Improvement in glucose tolerance after chronic administration of $3 \mathrm{MS}$ to diabetic patients was inconsistent, and could not be conclusively related to the action of the drug. Although acute doses of $3 \mathrm{MS}$ caused a fall in plasma FFA after $3-6 \mathrm{~h}$, chronic treatment gave no predictable change in fasting plasma FFA levels. - Because of side effects, 3 MS was not considered suitable for introduction as a therapeutic agent. The results, however, are of academic interest since it is the first demonstration of increased plasma insulin after an oral salicylate.

Effet de l'acide 3-méthyl salicylique (O-crésotinique) sur l'insuline plasmatique et la tolérance au glucose chez des sujets diabétiques et non-diabétiques

Résumé. L'administration orale d'acide 3-méthyl salicylique (3MS) à des sujets diabétiques et non-diabétiques, à faibles doses $(0.9-1.8 \mathrm{~g} / \mathrm{jour})$ pendant plusieurs mois produisait une augmentation significative des taux d'insuline plasmatique, une heure après une charge en glucose. Chez 2 sujets diabétiques, des doses aiguës avaient un effet semblable. - Une amélioration de la tolérance au glucose, après administration chronique de 3 MS à des patients diabétiques, n'a pas été décelée et n'a pas pu être reliée à l'action de la drogue de façon concluante. Bien que des doses aiguës de $3 \mathrm{MS}$ provoquassent une chute des FFA plasmatiques au bout de $3-6 \mathrm{hs}$, le traitement chronique ne causait pas de modification

The beneficial effect of salicylate in diabetes mellitus has been known for nearly a century. Large doses of sodium salicylate (up to $16 \mathrm{~g} /$ day) reduced the glycosuria and the symptoms in diabetic patients (Ebstein, 1876; Bartels, 1878; Williamson, 1901). Such large doses produced marked toxic effects, and severe diabetic acidosis and coma were not improved, so that this treatment failed to become popular.

From time to time, however, interest has been reawakened in the possible value of salicylate therapy in diabetes mellitus. Lowering of blood sugar in diabetic patients given salicylate in smaller doses $(5-8 \mathrm{~g} / \mathrm{day})$ was reported by Reid et al. (1957), Reid and Lightbody (1959) and Hecht and Goldner (1959). Reid and his colleagues showed that moderate ketonuria as well as glycosuria could be eliminated by aspirin therapy. prévisible des taux plasmatiques de FFA à jeun. - A cause des effets secondaires, le 3MS n'a pas été jugé valable en tant qu'agent thérapeutique. Les résultats cependant, sont d'intérêt académique, car c'est la première démonstration d'une élévation del'insuline plasmatique après administration orale d'un salicylate.

Wirkung der 3-Methyl-Salicyl (O-Kresotin) Säure auf das Plasmainsulin und die Glucosetoleranz bei Diabetikern und Nichtdiabetikern

Die orale Zufuhr von 3-Methyl-Salicylsäure (3MS) in relativ niedrigen Dosen $(0.9-1.8 \mathrm{~g} / \mathrm{Tag})$ an Diabetiker und stoffwechselgesunde Patienten über mehrere Monate führte zu einem signifikanten Anstieg der Plasmainsulinspiegel eine Stunde nach Glucosebelastung. Bei 2 Diabetikern riefen akuto Gaben einen ähnlichen Effekt hervor. - Die Besserung dor Glucosetoleranz nach chronischer 3 MS Verabreichung an Diabetiker war nur vorübergehend und konnte nicht mit Sicherheit auf das Medikament zurückgeführt werden. Obwohl es $3-6$ Std nach akuten Gaben von $3 \mathrm{MS}$ zu einem Abfall der FFS-Konzentrationen im Plasma kam, löste die chronische Zufuhr keine vorhersagbaren Veränderungen der FFS-Spiegel im Nüchtern-Plasma aus. - Wegen seiner Nebenwirkungen erscheint uns die 3MS zur Einführung in die Therapie nicht als geeignet. Die Ergebnisse sind aber von akademischem Interesse, da mit ihnen zum ersten Mal ein Anstieg der Plasmainsulinspiegel nach oraler Salicylatzufuhr nachgewiesen werden konnte.

Key-words: 3-methyl salicylic acid, o-cresotinic acid, hydroxytoluic acid, plasma insulin, glucose tolerance, diabetes, plasma free fatty acids.

Effective treatment of elderly diabetic patients by small doses of aspirin has been reported by Anderson and Thompson (1963) but this work is unconfirmed, and the consensus of opinion is that a minimum of about $5 \mathrm{~g}$ aspirin per day is the dose required to provide useful control of hyperglycaemia and glycosuria. Reid and Lightbody (1959) found that toxic effects were still troublesome at these dose levels, and emphasised the need for control of the treatment by plasma salicylate levels.

Lightbody and Reid (1960) examined various salicylate compounds for their possible value in diabetes mellitus, and among these were acetyl-o-cresotinic acid and sodium 3-methyl salicylate (orthocresotinate). These compounds had the advantage that, whilst their hypoglycaemic effect was similar to that of aspirin, 
they did not cause tinnitus or deafness. At a dosage of $5 \mathrm{~g}$ or more per day, other side-effects were still a problem, and were attributed to the high serum ocresotinate levels. Once again, therefore, this treatment failed to gain acceptance.

The present paper is concerned with a new study of 3-methyl salicylic (o-cresotinic) acid in diabetic and non-diabetic subjects. During the course of a study of the effect of this salicylate compound on plasma cholesterol and free fatty acids (FFA) (Howard et al., 1971), it occurred to us that the drug might have a significant effect on carbohydrate metabolism in doses smaller than those previously used.

The half-life of $3 \mathrm{MS}$ in man is $19-22 \mathrm{~h}$ (Cummings and Martin, 1965) and is not dose dependent. The halflives of aspirin and sodium salicylate are of this order only when very large doses are given; with low doses, the half-life of aspirin or sodium salicylate is only $3-4 \mathrm{~h}$ (Cummings and Martin, 1964). It therefore seemed that low or modest doses of 3MS might produce significant effects on carbohydrate and lipid metabolism without toxic side-effects. Our preliminary studies on subjects with raised blood lipids showed that small doses of 3MS $(0.9 \mathrm{~g} /$ day $)$ were well-tolerated and a single dose produced a fall in plasma FFA lasting several hours (Nature, 1967; Howard et al., 1968). In view of current thought on the aetiology of diabetes mellitus and the relationship between glucose and FFA metabolism (Randle et al., 1963; Hales, 1966) it was decided to study the effect of $3 \mathrm{MS}$ in diabetic subjects. If improved glucose tolerance could be achieved without toxic side-effects, a further useful oral anti-diabetic agent would be available.

\section{Materials and Methods}

3-methyl salicylic acid, (ortho-cresotinic acid) has the formula shown in Fig. 1. Its approved name is hydroxytoluic acid. For convenience and to keep this paper in line with our other communications concerning this drug (Nature, 1967; Howard et al., 1968; Howard et al., 1971) we shall henceforth refer to it as 3-methyl salicylic acid or 3MS.<smiles>Cc1ccccc1O</smiles>

Fig. 1. 3-methyl salicylic acid

Design of study. The study was performed in two parts.

I) "Acute" effect of $3 M S$ on glucose tolerance and plasma insulin

a) Glucose tolerance and plasma insulin.

5 patients attending the Department of Geriatric Medicine, Chesterton Hospital, Cambridge, had a $2 \frac{1}{2} \mathrm{~h}$
$50 \mathrm{~g}$ glucose tolerance test performed, starting $2 \mathrm{~h}$ after a single dose of $900 \mathrm{mg}$ 3MS orally. Preliminary tests on fasting normal subjects had shown a maximum depression of plasma FFA between 2 and $4 \mathrm{~h}$ after a dose of $900 \mathrm{mg} 3 \mathrm{MS}$, over the period of maximal plasma salicylate levels (Fig. 2). 4 of the subjects were also tested using a placebo (of low carbohydrate content) in place of 3MS. At least one week elapsed between the two tests. 1 patient had normal initial glucose tolerance; the others were all abnormal, 4 being frankly diabetic.
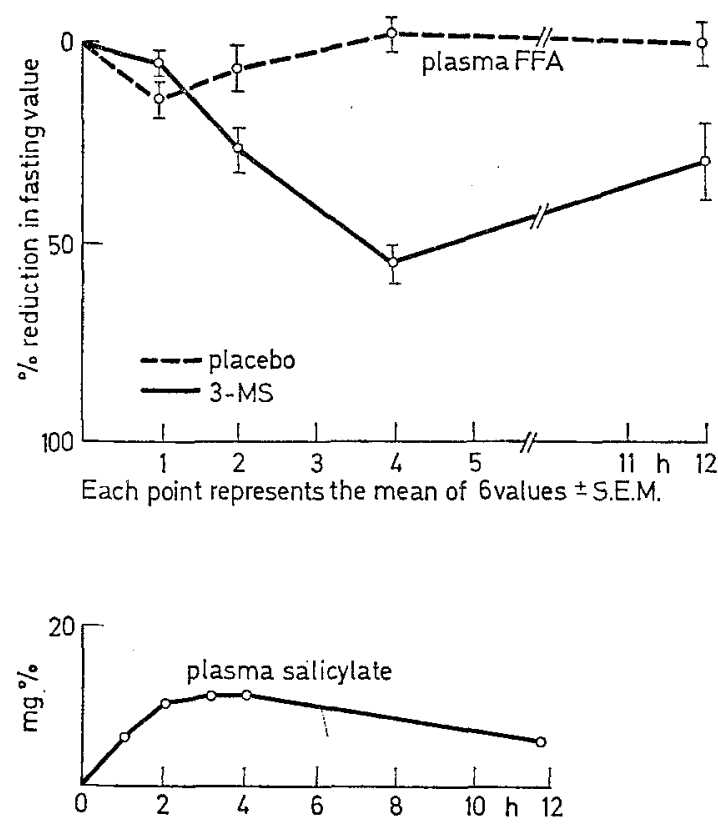

Fig. 2. Effect of a single dose of $3 \mathrm{MS}$ (900 $\mathrm{mg}$ ) on plasma salicylate and plasma FFA levels in fasting man

Tests performed: On each blood specimen, blood glucose, plasma insulin and free fatty acid levels were determined. Blood glucose was determined by the glucose oxidase method using the Technicon autoanalyzer modified from Hill and Kessler (1961), plasma insulin by the immunoassay method (Hales and Randle, 1963) and plasma FFA by the method of Dole (1956), after the heptane phase extracts had been washed with $2-3 \mathrm{ml} 0.1 \%$ ferric nitrate in $0.04 \%$ nitric acid in order to avoid the interference of salicylates in the titration.

b) Effect of single dose of $3 M$ S on plasma insulin in non-diabetic subjects

Two small studies were performed by taking serial blood samples at various times after administration of a single dose of $900 \mathrm{mg}$ 3MS to fasting non-diabetic subjects. In the first study, there were 9 subjects given $3 \mathrm{MS}$, and comparisons were made with 4 subjects given placebo (of low carbohydrate content) and 2 given 
aspirin B.P. (900 mg). Blood was taken at 1 and $2 \mathrm{~h}$ after the drug was given. In the second study, 5 different subjects received $3 \mathrm{MS}$, and 4 received aloxiprin, $1200 \mathrm{mg}$. Blood was taken hourly for four hours. Plasma insulin was assayed on each specimen.

\section{Results}

I) "Acute" effects of $3 M S$

a) Glucose tolerance tests in diabetics

In the 5 diabetic subjects on whom a glucose

Table 1. Glucose tolerance tests in two diabetic patients before and after a single dose of 3-MS given two hours before test

\begin{tabular}{|c|c|c|c|c|c|c|c|c|}
\hline Subject & Treatment & Blood analysis ${ }^{a}$ & Time & after & gluco & & & \\
\hline & & & $\frac{-2^{b}}{(h)}$ & $\begin{array}{l}0 \\
\text { (h) }\end{array}$ & $\begin{array}{l}1 / 2 \\
(\mathrm{~h})\end{array}$ & $\begin{array}{l}1 \\
\text { (h) }\end{array}$ & $\begin{array}{l}11 / 2 \\
(h)\end{array}$ & $\begin{array}{l}21 / 2 \\
\text { (h) }\end{array}$ \\
\hline E.P. & None & Insulin $\mu$ units $/ \mathrm{ml}$ & 18 & 20 & 32 & 35 & 55 & 47 \\
\hline & & Glucose $\mathrm{mg} \%$ & 292 & 257 & 270 & 311. & 320 & 311 \\
\hline & & $\mathrm{FFA} \mu \mathrm{Eq} / \mathrm{L}$ & 1100 & 930 & 700 & 700 & 600 & 575 \\
\hline & 3-MS & Insulin $\mu$ units $/ \mathrm{ml}$ & 20 & 60 & 74 & 84 & 84 & 87 \\
\hline & $(0 \cdot 9 \mathrm{~g})$ & Glucose $\mathrm{mg} \%$ & 290 & 255 & 270 & 290 & 325 & 310 \\
\hline & & $\mathrm{FFA} \mu \mathrm{Eq} / \mathrm{L}$ & 1000 & 780 & 610 & 630 & 500 & 500 \\
\hline C.C. & None & Insulin $\mu$ units $/ \mathrm{ml}$ & - & 14 & 30 & 38 & 31 & 23 \\
\hline & & Glucose $\mathrm{mg} \%$ & - & 135 & 240 & 250 & 245 & 150 \\
\hline & & $\mathrm{FFA} \mu \mathrm{Eq} / \mathrm{L}$ & - & 725 & 500 & 300 & 225 & 275 \\
\hline & 3-MS & Insulin $\mu$ units $/ \mathrm{ml}$ & 25 & 43 & 63 & 61 & 54 & 53 \\
\hline & $(0.9 \mathrm{~g})$ & Glucose $\mathrm{mg} \%$ & 210 & 170 & 275 & 315 & 275 & 230 \\
\hline & & FFA $\mu \mathrm{Eq} / \mathbf{L}$ & 875 & 375 & 400 & 300 & 375 & 275 \\
\hline
\end{tabular}

a Plasma analysis for Insulin and FFA. Whole blood for glucose.

b Time just before 3-MS given

\section{II) "Chronic" administration of $3 M S$ in diabetic patients}

5 diabetic patients attending Chesterton Hospital and the West Suffolk Hospital, age range 53-66 years, were treated with 3 MS for several months. No special diet was prescribed, although it was difficult to stop the patient cutting out sugar once he knew he was a diabetic. Initially the dose of $3 \mathrm{MS}$ was $0.9 \mathrm{~g} / \mathrm{day}$, but this gave plasma salicylate levels no higher than 12$13 \mathrm{mg} / 100 \mathrm{ml}$, and subsequently the dose was increased to $1.8 \mathrm{~g} /$ day. In one case, as much as $2.7 \mathrm{~g} /$ day was given for three months. Glucose-tolerance tests were performed at intervals, usually monthly or twomonthly. These tests were either full $21 / 2 \mathrm{~h}$ tests as described above, or partial tests consisting of blood samples taken fasting and one hour after the oral dose of $50 \mathrm{~g}$ glucose. Blood glucose, plasma insulin, and plasma FFA were assayed as described above. 2 patients, C.C. and E. P., were treated for 15 months; for three months of this period they were taking placebo instead of $3 \mathrm{MS}$, but they were not informed that any change had taken place in their tablets. W.T. was treated for 12 months, Q.A. for 10 months and F.R. for 8 months.

3 diabetic patients on insulin or oral agents, who were proving brittle or difficult to control, had 3MS $(1.8 \mathrm{~g} /$ day) added to their regimen in an attempt to improve control.

4 non-diabetic subjects who had received $3 \mathrm{MS}$ for long periods (at least 6 months) for hypercholesterolaemia were given a modified glucose tolerance test as above. tolerance test was performed, starting $2 \mathrm{~h}$ after $900 \mathrm{mg}$ 3MS, none showed an improved glucose tolerance.

Plasma insulin levels showed considerable increases in 2 cases (Table 1) and slight increases in 3 others.

Plasma FF $A$ fell $2 \mathrm{~h}$ after $3 \mathrm{MS}$ was given to fasting patients. During the subsequent glucose tolerance test, further falls in plasma FFA were small, and unaffected by 3 MS. Really low levels (below $200 \mu \mathrm{Eq} / \mathrm{l}$ ) were not reached.

b) Effect on plasma FFA and insulin in normal subjects

Plasma FFA fell when a single dose of $900 \mathrm{mg} 3 \mathrm{MS}$ was administered to fasting subjects (Fig. 2). No significant rise of plasma insulin was seen in any of the subjects treated acutely with $3 \mathrm{MS}$, aspirin, aloxiprin or placebo.

\section{III) Long-term effects of $3 M S$ on glucose tolerance}

Both E.P. (Fig. 3) and C.C. showed control of their diabetes to a satisfactory degree on $1.8 \mathrm{~g} 3 \mathrm{MS} /$ day as the sole treatment. When placebo was substituted for the active drug there was no real tendency to relapse, however, so that it was difficult to be certain that the improvement was not spontaneous.

Q.A. was controlled satisfactorily by 3 MS. F.R. and W.T. both showed a deterioration of glucose tolerance despite the administration of $3 \mathrm{MS}$, although F.R. finally reverted to his initial mild diabetic state after 9 months, presumably part of the spontaneous variation which the disease may show.

The three diabetics to whose drug regimen 3MS was added all showed. a smoothing of control of blood sugar, with decreased needs of insulin or sulphonylurea. 

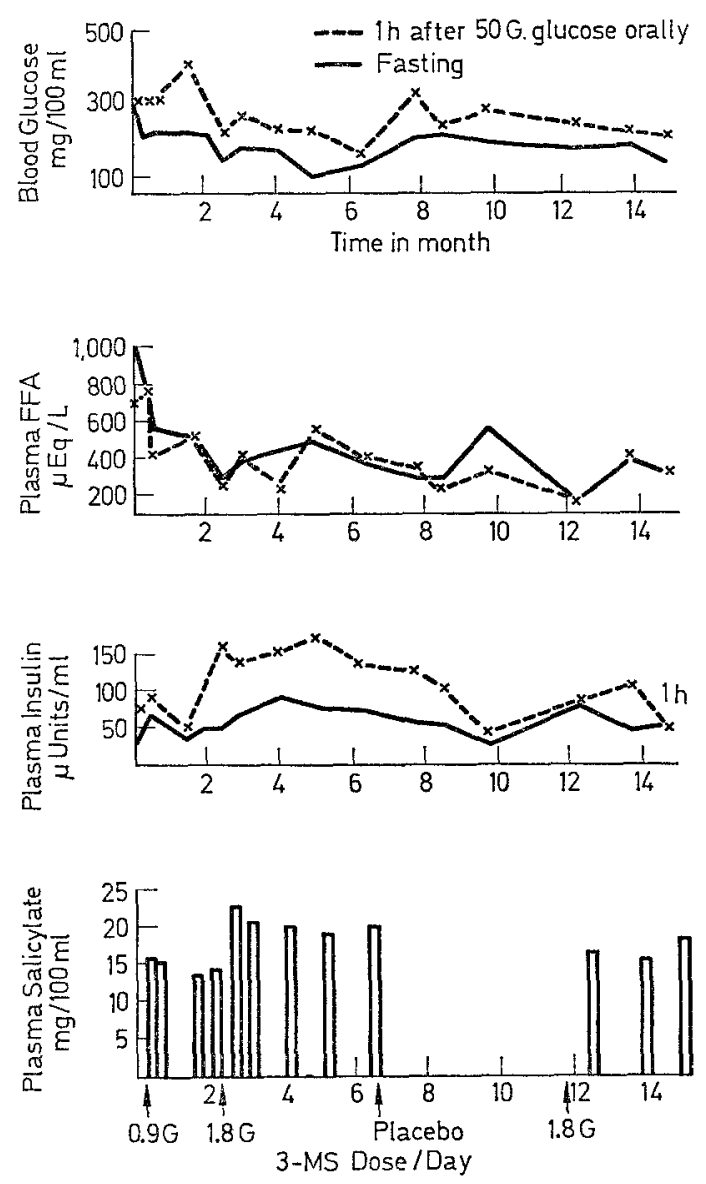

Fig. 3. Blood glucose, FFA, insulin and salicylate in a patient (E.P.) with mild maturity-onset diabetes treated with 3 MS or placebo
3MS for several months (Table 2). Fasting plasma insulin levels were also elevated in some of these patients, but the results were not statistically significant.

It has been stated that an individual's plasma insulin pattern tends to remain fairly constant, but it is not known whether this holds true for diabetics. We have noted one diabetic, treated on diet alone, whose plasma insulin values showed little variation during the course of twelve months.

The changes in plasma insulin patterns were not necessarily associated with changes in glucose tolerance.

Plasma FFA. Our results were variable and no definite pattern emerged.

Plasma salicylates. The aim of producing reasonably high plasma salicylate levels (say $25 \mathrm{mg} \%$ ) by using moderate doses of 3MS was not adequately achieved. Doses of $900 \mathrm{mg} /$ day 3MS gave plasma salicylate levels of only $12-13 \mathrm{mg} \%$. Even doses of $2.7 \mathrm{~g} /$ day increased plasma salicylate to only $24 \mathrm{mg} \%$, and it was felt that this dose was too high for routine use.

However, it should be noted from Fig. 3 that rises in plasma insulin levels tended to follow elevations of plasma salicylate. Nevertheless, it was not possible to demonstrate a concomitant improvement in glucose tolerance in most of the patients.

Side effects of $3 M S$. Drowsiness was the only sideeffect noted in this study. It occurred in three patients taking 3MS for several months. Two of these patients did not notice it for some time, but commented on the absence of a feeling of tiredness once they changed to the placebo. The third patient, after several months' treatment, began to omit his morning dose because the drowsiness interfered with his work at that time.

Table 2. Plasma insulin in patients receiving 3-MS

\begin{tabular}{|c|c|c|c|c|}
\hline & & & $\begin{array}{l}\text { Plasma insulin } \\
\mu \text { units } / \mathrm{ml} \text { (means }\end{array}$ & \pm S.E.M.) \\
\hline Group & Type & $\begin{array}{l}\text { Number } \\
\text { of } \\
\text { patients }\end{array}$ & Fasting & $\begin{array}{l}1 \mathrm{~h} \text { after glucose } \\
\text { (50 g orally) }\end{array}$ \\
\hline 1 & Before treatment & 5 & $16 \cdot 0 \pm 2 \cdot 9$ & $39 \cdot 2 \pm 14 \cdot 1$ \\
\hline 2 & $\begin{array}{l}\text { Early stage of } \\
\text { treatment with } \\
\text { 3-MS }\end{array}$ & 5 & $31 \cdot 8 \pm 8 \cdot 7$ & $104 \cdot 8 \pm 21 \cdot 1$ \\
\hline $\mathbf{3}$ & $\begin{array}{l}\text { Late stage of } \\
\text { treatment with } \\
\text { 3-MS }\end{array}$ & 7 & $100 \pm 37 \cdot 8$ & $179 \pm 33 \cdot 1$ \\
\hline 4 & $\begin{array}{l}\text { After treatment } \\
\text { Significance }\end{array}$ & 7 & $\begin{array}{l}19 \cdot 5 \pm 7 \cdot 4 \\
\text { Group } 1 \& 2 \mathrm{NS} \\
\text { Group } 3 \& 4 \mathrm{NS}\end{array}$ & $\begin{array}{l}63 \cdot 3 \pm 23 \cdot 9 \\
\text { Group } 1 \& 2 P<0 \cdot 05 \\
\text { Group } 3 \& 4 P<0.05\end{array}$ \\
\hline
\end{tabular}

NS : not significant

Plasma insutin levels (Fig. 3, Tables 1 and 2). All the diabetic subjects had a fasting plasma insulin of $23 \mu \mathrm{u} / \mathrm{ml}$ or below at the start of this study.

The most striking result in these trials was the rise in plasma insulin levels $1 \mathrm{~h}$ after a glucose load, which was a constant feature in the diabetic and the nondiabetic hypercholesterolaemic patients treated with

\section{Discussion}

Although effective oral antidiabetic agents have been available for several years now, none are without some risk or side-effect. The major risk, particularly in the elderly, is the development of hypoglycaemia and the advantage of salicylates is that whilst they 
may lower blood sugar and abolish glycosuria and even moderate ketonuria, they do not produce hypoglycaemia (always excepting acute salicylate intoxication, in which hypoglycaemia has been reported (Barnett et al., 1942; Cotton and Fahlberg, 1964) and the rare idiosyncrasy (Limbeck et al., 1965)). Their effectiveness, however, seems to depend on high plasma salicylate concentrations, which has meant the administration of large doses, with inevitably the appearance of other troublesome side-effects, notably tinnitus, deafness, bleeding from gastric erosions, and metabolic stimulation. Thus, Reid and Lightbody (1960) aimed to achieve blood levels of $35-45 \mathrm{mg} / 100 \mathrm{ml}$ serum, and by maintaining these levels they could progressively reduce the need for insulin in diabetic patients. In this way they established the insulin-equivalence of aspirin during a $2-3$ week course of treatment. Of 14 patients, all had lowered insulin requirements whilst on aspirin -8 came off insulin, 5 needed $10-20$ units less but remained brittle, and 1 had a reduction of 72 units, with better results than on his initial 112 units per day. The maximum insulin requirement completely replaceable by aspirin was 48 units per day. Apart from the absence of hypoglyeaemia due to aspirin, the frequency of hypoglycaemic attacks in patients requiring large doses of insulin may be reduced by combining insulin and aspirin therapy; furthermore, there seems to be an increasing response to aspirin as the insulin requirement increases.

It will thus be apparent that if these beneficial effects could be achieved by the development of a salicylate with a longer action and a lesser tendency to side-effects, a useful new antidiabetic agent would have been evolved. 3MS seemed to offer considerable promise in this respect - its relatively long half-life of 18-20 hours suggested that moderate doses might allow a safer build-up of plasma salicylate levels, and the side-effects seen with large doses of aspirin should thus be avoidable. In the event, this drug did not live up to its promise, for even doses of $2.7 \mathrm{~g} /$ day failed to produce plasma salicylate levels much above $20 \mathrm{mg}$ $100 \mathrm{ml}$, and drowsiness was an annoying if not always important side-effect. Nevertheless, some of the changes produced in carbohydrate metabolism by $3 \mathrm{MS}$ administration were of interest and are worthy of comment.

3MS and glucose tolerance. The concept of a glucosefatty acid cycle (Randle et al., 1963) has led to the suggestion that in diabetes mellitus the primary abnormality may lead to an increased availability of fatty acids for oxidation (which may be seen in the presence of normal or supranormal plasma insulin concentrations), and that this leads to impaired glucose oxidation (Hales, 1966). Experimental elevation of plasma FFA concentrations has been accompanied by a loss of oral glucose tolerance and of sensitivity to endogenous insulin (Felber and Vanotti, 1964; Thorell et al., 1966). Efforts have been made to improve glucose tolerance by acute reductions in plasma FFA (Hales et al., 1966). These workers administered large doses of nicotinic acid prior to glucose tolerance tests. These large doses are liable to cause troublesome side-effects, however, and long-term oral therapy with such doses of nicotinic acid is not practicable.

Many other drugs, including salicylates, (Carlson and Ostman, 1961, 1965; Bizzi et al., 1965; Garattini and Bizzi, 1966) depress plasma FFA.

Field et al. (1967) used infusions of sodium salicylate, and found that this improved intravenous ghucose tolerance in mild diabetics and healthy controls, but that this occurred without depression of plasma FFA.

Lightbody and Reid (1960) had shown that im. proved glucose tolerance followed two weeks of salicylate treatment in large doses: glucose tolerance curves were similar in shape to the originals but lower. They obtained similar results with $3 \mathrm{MS}$, in doses sufficient to produce plasma levels of $35 \mathrm{mg} \%$. Above this level, toxic effects were noted (see below). Plasma FFA levels were not assayed by these workers.

The present study attempted to achieve improved glucose tolerance with lower plasma salicylate levels, and the opportunity was taken to observe plasma FFA and plasma insulin concentrations at the same time. It is well known that salicylates may reduce plasma FFA (Carlson and Ostman, 1961, 1965), and we have shown that 3MS was no exception to this when given acutely, but there was no sustained fall in FFA in the diabetic patients to whom the drug was given over a long period; nor could we demonstrate with certainty an improvement in glucose tolerance. Nevertheless, a finding of great interest which did appear was the rise in plasma insulin levels produced by 3MS.

Salicylates and plasma insulin levels. The exact mechanism by which salicylates lower blood sugar levels is not known. Most work to date suggests a peripheral mechanism: increased glucose uptake has been found in isolated rat diaphragms in vitro (Randle and Smith, 1958; Manchester et al., 1958) - though this was not confirmed by other workers (Segal et al., 1960; Huggins and Smith, 1962); increased peripheral utilisation of glucose (Segal et al., 1960) (which is said to be distinct from the metabolic stimulant (uncoupling) effects of salicylates - Reid, 1958; Gilgore, 1960; Stowers, 1963); and/or a direct effect on the liver, reducing glycogenolysis or gluconeogenesis (Stowers et al., 1959; Manchester et al., 1958).

It has been reported that some of the biochemical changes in salicylate-treated diabetics resembled those seen after insulin administration (Stowers et al., 1959), but there are also many points of difference (Stowers, 1963; Gilgore and Rupp, 1961; Manchester et al., 1958). The consensus of opinion hitherto has been against the idea that the hypoglycaemic action of salicylate is mediated by an increase in the release of insulin (Hecht and Goldner, 1959; Carlson and Ostman, 1961; Gilgore and Rupp, 1961). Seltzer (1962) was unable to find any increase in the levels of insulin in 
pancreatic venous blood in dogs treated with salicylate infusions, and Limbeck et al. (1965) failed to show any increase in plasma-insulin in a patient in whom hypoglycaemia developed following only $300 \mathrm{mg}$ aspirin orally. Further, salicylates exert a hypoglycaemic effect in alloxan-diabetic rats (Smith et al., 1952) and also in partially-pancreatectomised rats (Ingle and Meeks, 1952), and it has been noted that the hypoglycaemic effects of salicylates and sulphonylureas are additive (Stowers et al., 1959), which speaks against a common mechanism of action. In addition, experiments on rabbit pancreas in vitro have shown that uncoupling agents (including salicylates) actually inhibit the glucose-stimulated secretion of insulin (Randle et $a l ., 1963)$.

It seems unlikely, therefore, that salicylates stimulate the secretion of insulin from the islets of Langerhans; and yet there are certain recent observations of increased plasma-insulin levels after salicylates which require explanation. Thus, Field et al. (1967) found significant elevations in plasma insulin levels at the end of one hour of intravenous infusion of sodium salicylate. The infusion was continued for a further hour, and the raised plasma insulin levels persisted for a total of $4 \mathrm{~h}$. In addition, plasma insulin levels were higher during intravenous glucose tolerance tests (started $4 \mathrm{~h}$ after the salicylate infusion was begun) than in similar tests performed after a saline infusion. (Each subject served as his own control). These changes were accompanied by faster half-time for glucose disappearance, i.e. an improvement in glucose tolerance, as mentioned earlier; there was no significant effect on plasma FFA.

The present study has demonstrated elevations in plasma insulin, both fasting and during oral glucose tolerance tests, following long-term oral administration of a salicylate derivate. This is, to our knowledge, the first time that such an observation has been made.

Its mechanism remains speculative. Various possibilities suggest themselves -

I Displacement of free insulin from the protein-bound form. Salicylates are extensively bound to plasma albumin (Reynolds and Cluff, 1960); the effect is greater for sodium salicylate than for aspirin (Lester et al., 1946) but greater still for 3MS (Stafford, 1962).

II Mobitization of insulin from the tissues

III Inhibition of insulinase

IV Artefact due to interference by $3 M S$ in the insulin assay

We have checked this last point and find no such interference.

\section{Toxic effects of $3 M S$}

$3 \mathrm{MS}$ in modest doses had few side-effects in this study.

Tinnitus and deafness do not occur even with high doses (Stockman, 1912; Lightbody and Reid, 1960) and radioactive chromium studies (Wood et al., 1962) have shown no significant gastro-intestinal blood loss after $4 \mathrm{~g}$ 3MS per day for 5 days in 11 patients, one of whom had had haematemesis previously, attributed to aspirin, and three others known to have peptic ulcer.

Anorexia, nausea, vomiting, headache, were reported. by Lightbody and Reid (1960), using large doses $(4-5 \mathrm{~g} /$ day) for 2 or 3 weeks.

It the present study we did not meet these symptoms, but we have met them not infrequently in other patients and in normal subjects treated with very modest doses of 3MS in our study of the hypocholesterolaemic properties of 3MS (Howard et al., 1971). In our experience, the commonest of these side-effects is vomiting, and this may necessitate stopping the tablets completely.

Drowsiness, though not a great problem in this study, was real enough, and again we have noted it commonly in our other trials with 3MS. In fact, it has been the commonest side-effect in our patients. This symptom is of interest because of the popular concept that aspirin helps to induce sleep, even in subjects without pain. This idea is based on experience rather than formal trial, but there are several interesting references in the literature to the sedative or tranquillizing properties of aspirin (Kaufman, 1927; Lespagnol et al., 1963; Krumholz et al., 1964, 1965; Pfeiffer et al., 1965). It would appear that this sedative property is enhanced in the derivative we have been studying, viz., 3MS.

Cardiac effects. Large doses of salicylates have long been known to have a depressant effect on the heart (Macdougall and Alexander, 1963). 3MS is no different in this respect (Stockman, 1912). We found no cardiac effects in the patients in this study. It should be mentioned, however, that in another study, on 12 younger hypercholesterolaemic subjects, two cases of paroxysmal tachycardia occurred on doses of $900 \mathrm{mg}$ 3MS twice daily - one case after 6 weeks and one after 16 weeks (Renton, 1968). Although the evidence implicating 3MS was circumstantial, it was decided to stop further work on this drug. More recently, animal experiments have indicated that some atrophy of the seminiferous tubules of the testes may follow administration of 3MS (Renton, 1968). As a result, it has not been developed further, nor is it proposed to place it on the market. (Cruder preparations have been used in clinical trials for 60 years (May, 1909) - and the o-acetyl derivative has been obtainable on the continent for some years).

Despite the fact that 3MS proved unsuitable for administration to patients, the importance of the work described here is the demonstration that a salicylate compound, administered orally, can raise plasma insulin levels, especially in response to a glucose load. This should have useful implications for further research into the ever fascinating salicylates and their possible value as anti-diabetic and hypolipaemic agents. 
Acknowledgements: This study was supported by Public Health Service grants (1 RO1 HE 09969 and 1 RO1 HE 09971) from the National Institutes of Health, Bethesda, Md. and Aspro Nicholas Ltd., Slough, England who also generously supplied 3-methyl salicylic acid.

We gratefully acknowledge the technical assistance of $\mathrm{Mr}$. M. Brown and Mrs. A. Bright.

\section{References}

Anderson, W.F., Thompson, J.: Aspirin in the treatment of diabetes mellitus in the elderly. Geront. clin. 5, 234$243(1963)$.

Barnett, H.L., Powers, J.R., Benward, J.H., Hartmann, A. F.: Salicylate intoxication in infants and children. J. Pediat. 21, 214-223 (1942).

Bartels, K.: Über die therapeutische Verwertung der Salicylsäure und ihres Natronsalzes in der inneren Medizin. Dtsch. med. Wschr. 4, 423-425 (1878).

Bizzi, A., Garattini, S., Veneroni, E.: The action of salicylate in reducing plasma free fatty acids and its pharmacological consequences. Brit. J. Pharmacol. 25, $187-196$ (1965).

Carlson, L.A., Ostman, J. : Effect of salicylates on plasma free fatty acid in normal and diabetic subjects. Metabolism 10, 781-787 (1961).

- - Inhibition of the mobilisation of free fatty acids from adipose tissue in diabetes. II. Effect of nicotinic acid and acetylsalicylate on blood glucose in human diabetics. Acta med. scand. 178, 71-79 (1965).

Cotton, E.K., Fahlberg, V.I. : Hypoglycemia with salicylate poisoning. A report of two cases. Amer. J. Dis. Child 108, 171-173 (1964).

Cummings, A.J., Martin, B.K.: Factors influencing the plasma salicylate concentration and urinary salicylate excretion after oral dosage with aspirin. Biochem. Pharmacol. 13, 767-776 (1964).

Cummings, A.J., Martin, B.K.: A kinetic study of the elimination of 3-methyl salicylic acid and its acetyl derivative in man. Brit. J. Pharmacol. 25, $470-480$ (1965).

Dole, V.P: A relation between non-esterified fatty acids in plasma and in the metabolism of glucose. J. clin. Invest. 35, 150-154 (1956).

Ebstein, W.: Zur Therapie des Diabetes mellitus, insbesondere über die Anwendung des salicylsauren Natron bei demselben. Berl. klin. Wschr. 13, 337-340 (1876).

Felber, J.P., Vanotti, A.: Effects of fat infusion on glucose tolerance and insulin plasma levels. Med. Exp. 10, $153-156$ (1964).

Field, J.B., Boyle, C., Remer, A.: Effect of salicylate infusion on plasma-insulin and glucose tolerance in healthy persons and mild diabetics. Lancet 1967 I, $1191-1194$.

Garattini, S., Bizzi, A.: Effect of drugs on mobilization of free fatty acid. Pharmacol. Rev. 18, 243-251 (1966).

Gilgore, S.G.: The influence of salicylate on hyperglycemia. Diabetes 9, 392-393 (1960).

Gilgore, S.G., Rupp, J.J.: Response of blood glucose to intravenous salicylate. Metabolism 10,419-421 (1961).

Hales, C.N.: The glucose-fatty acid cycle and the aetiology of diabetes. Proc. nutr. Soc. 25, 61-66 (1966).

- Randle, P.J.: Immunoassay of insulin with insulinantibody precipitate. Biochem. J. 88, 137-146 (1963).

- Stein, J., Stowers, J.M.: Rein et Foie, Maladies de la Nutrition, 9, 387-401 (1966).

Hecht, A., Goldner, M.G.: Reappraisal of the hypoglycemic action of acetylsalicylate. Metabolism 8, 418-428 (1959).

Hill, J.B., Kessler, E.: An automated determination of glucose utilising a glucose oxidase-peroxidase system. J. Lab. clin. Med. 57, 970-980 (1961).
Howard, A.N., Gresham, G.A., Bowyer, D.E., Hyams, D.E.: The use of baboons in the evaluation of drugs active against atherosclerosis. In Vagtbord, H. (ed.): Use of non human primates in drug evaluation, pp. 480-493. Austin and London: University of Texas Press 1968.

- Hyams, D.E., Everett, W., Jennings, I.W., Gresham, G.A., Bizzi, A., Garattini, S., Veneroni, E., Miettinen, T.: 3-methyl salicylic acid: a long-acting salicylate which decreases free fatty acid mobilisation and plasma cholesterol. Europ. J. Pharmacol. 13, 244-253 (1971).

Huggins, A.K., Smith, M.J.H.: Uncoupling reagents and metabolism. 5. Effects of salicylate and of 2:4 dinitrophenol on the metabolism of isolated rat diaphragm. Biochem. J. 85, 394-402 (1962).

Ingle, D.J., Meeks, R.C.: Suppression of glycosuria during administration of large doses of aspirin to force-fed partially depancreatectomized rate. Amer. J. Physiol. $171,600-603$ (1952).

Kaufman, H.P.: Arzneimittel synthetische Studien I: Die Bedeutung der Acylreste in acylierten Heilmitteln. Ang. Chem. 40, 69 (1927).

Krumholz, W.V., Sheppard, C., Merlis, S.: Studies with aspirin: psychopharmacologic and methodologic considerations. Clin. Pharmacol. Ther. 5, 691-694 (1964).

- - - Studies with acetylsalicylic acid. II. Psychopharmacologic and methodologic considerations. Clin. Pharmacol. Ther. 6, 359-361 (1965).

Lespagnol, A., Bizard, G., Robelet, A., Devillers, F.: Recherches dans la serie salicylique. Therapie 18, 155169 (1963).

Lester, D., Lolli, G., Greenberg, L.A.: The fate of acetylsalicylic acid. J. Pharmacol. 87, $329-342$ (1946).

Lightbody, T.D., Reid, J.: Ortho-cresotinate and diabetes mellitus. Brit. med. J. 1960 II, 1704-1707.

Limbeck, G.A., Ruvalcaba, R.H. A., Samols, E., Kelley, V.C.: Salicylate and hypoglycemia. Amer. J. Dis. Child 109, 165-167 (1965).

Macdougall, A.I., Alexander, W.D.: Effects of Salicylates on Cholesterol Metabolism. Salicylates - An International Symposium. Editors: Dixon, A. St. J., Martin, B.K., Smith M.J.H., Wood P.H.N. p. 92-96. London: J. \&A. Churchill Ltd. 1963.

Manchester, K.I., Randle, P.J., Smith, G.H.: Some effects of sodium salicylate on muscle metabolism. Brit. med. J. 1958 I, $1028-1030$.

May, R.: The action of cresotinic acids and toluic acids. Brit. med. J. 1909 II, $791-793$.

Nature: Free fatty acid mobilization. Nature 214, 758 (1967).

Pfeiffer, C.C., Goldstein, L., Murphree, H.B.: The C.N.S. effect in man of mild analgesics as measured by quantitative analysis of the electroencephalogram. J. new Drugs 5, 260 (1965).

Randle, P.J., Garland, P.B., Hales, C.N., Newsholme, E.A.: The glucose fatty acid cycle: its role in insulin sensitivity and the metabolic disturbance of diabotes mellitus. Lancet 1963 I, 785-789.

- Smith, G.H.: Regulation of glucose uptake by muscle. I. The effects of insulin, anaerobiosis and cell poisons on the uptake of glucose and the release of potassium by isolated rat diaphragm. Biochem. J. 70, 490-500 (1958).

Reid, J.: Dinitrophenol and diabetes mellitus: A comparison with salicylate. Brit. med. J. 1958 II, 724-727.

- Lightbody, T.D.: The insulin equivalence of salicylate. Brit. med. J. 1959 I, 897-900.

- Macdougall, A.I., Andrews, M.M.: Aspirin and diabetes. Brit. med. J. 1957 II, 1071-1074.

Renton, R.: Personal communication (1968). 
Reynolds, R.C., Cluff, L.E.: Interaction of serum and sodium salicylate. Changes during acute infection and its influence on pharmacological activity. Bull. Johns Hopkins Hosp. 107, 278-290 (1960).

Segal, S., Blair, A., Weinberg, A.: In vitro effects of salicylate on carbohydrate metabolism. Metabolism $\mathbf{9}$, $1033-1046(1960)$.

Seltzer, H.S.: Quantitative effects of glucose, sulphonylureas, salicylate and indole-3-acetic acid on the secretion of insulin activity into pancreatic venous blood.J. clin. Invest. 41, 289-300 (1962).

Smith, M.J.H., Meade, B.W., Bornstein, J.: The effect of salicylate on glycosuria, blood glucose and liver glycogen of the alloxan-diabetic rat. Biochem. J. 51, 18$20(1952)$

Stafford, W.L.: The binding by bovine plasma and plasma fractions of salicylic acid and some of its 3-alkyl analogues. Biochem. Pharmacol. 2, 685-692 (1962).

Stockman, R.: The therapeutic actions of the cresotinic acids. J. Pharmacol. exp. Ther. 4, 97-102 (1912).

Stowers, J.M.: Salicylates and clinical diabetes, and remarks on other endocrine effects. Salicylates - An International Symposium. Editors: Dixon, A. St. J.,
Martin B.K., Smith, M.J.H., Wood, P.H.N.. p. $65-$ 70, Boston: Little and Brown 1963.

- Constable, L. W., Hunter, R. B.: A clinical and pharmacological comparison of chlorpropamide and other sulphonylureas. Ann. N.Y. Acad. Sci. 74, 689-695 (1959).

Thorell, J., Persson, B., Sterkey, G.: Effect of fat infusion on plasma glucose, FFA, gilycerol and insulin levels during intravenous and oral glucose tolerance tests. Diabetologia 2, 232 (1966).

Williamson, R.T.: On the treatment of glycosuria and diabetes mellitus with sodium salicylate. Brit. med. J. 1901 I, $750-762$.

Wood, P.H.N., Harvey-Smith, E.A., Dixon, A.St.J.: Salicylates and gastro-intestinal bleeding. Acetylsalicylic acid and aspirin derivatives. Brit. med. J. 1962 I, $669-675$.

\section{Dr. D.E. Hyams}

Guy's Hospital Dept. of

Geriatric Medicine

New Cross Hospital

Avonley Rd.

London S. E. 14., Great Britain 